\title{
EDUKASI GIZI SEIMBANG PADA KELOMPOK IBU BALITA DALAM MENINGKATKAN IMUNITAS BALITA MASA PANDEMI COVID-19
}

\author{
Sunesni $^{1}$, Eka Putri Primasari ${ }^{2}$, Yani Maidelwita ${ }^{3}$, Ralsy Mailiza Harni $^{4}$, Windy $^{2}$ \\ Sabrina Putri ${ }^{5}$, Ela Malasari6 \\ 1,5,6 Prodi S1 Kebidanan / STIKes MERCUBAKTIJAYA Padang, \\ 2,3 Prodi D III Kebidanan / STIKes MERCUBAKTIJAYA Padang, \\ ${ }^{4}$ Laboratorium Keperawatan \& Kebidanan / STIKes MERCUBAKTIJAYA Padang,
}

E-mail korespondensi: ekaputri28@gmail.com²

\begin{tabular}{l}
\hline Article History: \\
\hline Received: 4-11-2021 \\
Revised: 2-12-2021 \\
Accepted: 15-12-2021 \\
Kata Kunci : Edukasi, Gizi \\
Seimbang, Balita
\end{tabular}

Kata Kunci : Edukasi, Gizi
Seimbang, Balita

\section{Abstrak:}

Latar Belakang: Sembilan dari sepuluh anak mengalami kekurangan disedikitnya satu aspek kesejahteraan anak, seperti akses ke makanan dan gizi, kesehatan, pendidikan, perumahan, air dan sanitasi, serta perlindungan anak. Pandemi COVID-19 membuat adanya kemungkinan jumlah anak dengan kekurangan gizi kronis di Indonesia bertambah. Salah satu dampak pandemi Covid-19, kegiatan rutin seperti Posyandu menjadi tidak dapat dilaksanakan. Oleh karena itu sangat diperlukan kegiatan edukasi dan pendampingan pada kelompok ibu balita tentang pola atau kebutuhan gizi seimbang dalam meningkatkan imuntas balita masa pandemi Covid-19. Kegiatan ini dilaksanakan di Kelurahan Anduring, Kecamatan Kuranji, Kota Padang.

Metode: Pelaksanaan dilakukan dengan menyampaikan edukasi tentang deteksi gangguan gizi pada anak dan gizi seimbang untuk balita pada masa pandemi Covid-19 secara luring dengan mematuhi protokol kesehatan dengan ketat. Selanjutnya dilakukan pendampingan secara virtual dengan sharing informasi berupa leaflet, poster melalui media handphone. Kegiatan dilaksanakan tanggal 15 Desember 2020 dengan jumlah sasaran yang hadir 20 orang ibu-ibu balita. Kegiatan dievaluasi melalui pre test dan post test.

Hasil: Hasil dari kegiatan pengabdian ini didapatkan nilai rata-rata pengetahuan responden terkait materi edukasi yang diberikan mengalami peningkatan dari sebelum dan setelah dilakukan edukasi, dimana saat awal adalah 72,70 \pm 11,824 dan saat akhir setelah edukasi menjadi 77,55 \pm 9,495 .

\footnotetext{
Abstract:

Background: Nine out of ten children experience a deficiency in at least one aspect of child welfare, such as access to food and nutrition, health, education, housing, water and sanitation, and child protection. The COVID-19 pandemic makes it possible for the number of children with chronic malnutrition in Indonesia to increase. One of the impacts of the Covid-19 pandemic is that routine activities such as Posyandu cannot be carried out. Therefore, it is very necessary to carry out educational and mentoring activities for the
} 
Keywords: Education, Balanced Nutrition, Toddlers group of mothers of toddlers about the pattern or need for balanced nutrition in increasing the immunity of toddlers during the Covid-19 pandemic. This activity was carried out in Anduring Village, Kuranji District, Padang City.

Method: The implementation was carried out by delivering education on the detection of nutritional disorders in children and balanced nutrition for toddlers during the Covid-19 pandemic offline by strictly adhering to health protocols. Furthermore, virtual assistance was carried out by sharing information in the form of leaflets, posters through mobile phone. The activity was carried out on December 15, 2020 with a target number of 20 mothers of toddlers attending. Activities are evaluated through pre-test and post-test.

Result: The results of this service activity showed that the average value of respondents' knowledge related to the educational materials provided had increased from before and after education, where at the beginning it was $72.70 \pm$ 11.824 and at the end after education it became $77.55 \pm 9.495$.

\section{Pendahuluan}

Sembilan dari sepuluh anak mengalami kekurangan disedikitnya satu aspek kesejahteraan anak, seperti akses ke makanan dan gizi, kesehatan, pendidikan, perumahan, air dan sanitasi, serta perlindungan anak (UNICEF, 2017). Tiga penyebab langsung malnutrisi paling umum, yaitu: Praktik menyusui yang tidak memadai dan pola makan yang buruk, ditambah praktik pengasuhan yang tidak optimal; Nutrisi dan perawatan yang tidak memadai bagi ibu dan perempuan hamil; serta Tingginya angka penyakit menular utamanya akibat lingkungan tempat tinggal yang tidak bersih dan tidak memadainya akses ke layanan kesehatan yang kurang memadai (UNICEF, 2018). Pandemi COVID-19 membuat adanya kemungkinan jumlah anak stunting (kekurangan gizi kronis) di Indonesia bertambah. Sehingga diprediksi target penurunan stunting secara nasional hingga 14\% sulit dicapai, mengingat Posyandu tidak dapat beroperasi dan tenaga kesehatan di Puskesmas tidak luput dari dampak COVID-19 (Dinkes Surakarta, 2020).

Kelurahan Anduring terletak, Kecamatan Kuranji, Kota Padang dengan luas wilayah $\pm 4,04$ kilometer persegi. Untuk sampai ke Kelurahan Anduring ini bisa dilalui oleh kenderaan roda dua dan roda empat. Jarak tempuh dari STIKes MERCUBAKTIJAYA Padang ke Kelurahan Anduring $\pm 8,5 \mathrm{~km}$ (Google-Maps, 2020). Jumlah rumah tangga yang terdapat di kelurahan ini \pm 1429 rumah tangga dengan mata pencaharian utamanya sebagai wiraswasta dan petani. Sedangkan jumlah penduduknya sebanyak 14.809 jiwa dimana 1000 diantaranya balita (BPS, 2020). Survei daring yang dilakukan kepada 2 orang kader kesehatan menunjukkan bahwa hasil penimbangan yang dilakukan dengan kunjungan rumah ke rumah oleh kader dengan menggunakan protokol kesehatan Covid-19 sebagian besar Balita mengalami masalah dalam pertumbuhan Berat Badan (BB). Dimana dari 21 Balita yang dikunjungi dan ditimbang; $33,3 \%$ (7 orang) mengalami penurunan BB. $52,4 \%$ (11 orang) tidak mengalami kenaikan, dan hanya 14,3\% (3 orang) yang mengalami kenaikkan BB. 
Selanjutnya kader menyampaikan bahwa kondisi ini terjadi karena keluarga dalam hal ini ibu sebagai penyedia makanan mengurangi porsi makan karena masalah keuangan. Hilangnya pendapatan rumah tangga akibat pandemic Covid-19 meningkatkan risiko anak mengalami kurus dan kekurangan zat gizi mikro. Gizi buruk merupakan salah satu bentuk kekurangan gizi yang membahayakan. Risiko kematian pada anak dengan kondisi tersebut nyaris 12 kali lipat lebih tinggi daripada risiko kematian pada anak dengan gizi baik (UNICEF, 2018). Anak-anak yang pulih dari gizi buruk mungkin akan terus mengalami masalah perkembangan dan pertumbuhan selama hidupnya. Lebih jauh, berbagai upaya untuk menekan infeksi COVID-19 dapat mempersulit identifikasi dan pemberian perawatan serta layanan penting bagi anakanak yang mengalami gizi buruk.

Penanggulangan masalah gizi yang sudah dilakukan secara nasional diantaranya dengan meningkatkan jangkauan dan kualitas tatalaksana kasus gizi buruk di rumah tangga, puskesmas dan rumah sakit, serta pembentukan keluarga sadar gizi. Program pencegahan dan penanggulangan gizi buruk yang telah dilakukan pemerintah, antara lain promosi pemberian air susu ibu (ASI) eksklusif, pemberian makanan pendamping ASI, pemberian makanan tambahan, pemberian suplemen vitamin A dan zat besi, pendampingan keluarga, program pola asuh gizi, dan program keluarga sadar gizi (Arisman, 2011). Upaya-upaya itu diterjemahkan kedalam berbagai program pencegahan dan penanggulangan gizi buruk, baik di tingkat pusat maupun di tingkat daerah. Pada saat ini program kegiatan ini agak terhalang dengan adanya wabah Covid19 , sehingga program ini menjangkau masyarakat yang juga terbatas untuk datang ke layanan kesehatan.

Kondisi ini sangat diperlukan tidakan segera, dampak jangka panjang terhadap tingkat gizi dapat meningkatkan jumlah balita stunting dan wasting. Sangat diperlukan bentuk penyuluhan dan pendampingan pada kelompok ibu balita - termasuk pemantauan dan penyuluhan terkait pertumbuhan, pemberian suplemen zat gizi mikro, konseling mengenai pola makan, serta jika diperlukan pemberian makan tambahan. Dari kenyataan tersebut kami tim Pengabdi Sekolah Tinggi Kesehatan MERCUBAKTIJAYA Padang, merasa berkewajiban untuk melakukan suatu kegiatan yang bisa membantu masyarakat di era pandemi Covid-19 ini, terutama dalam hal meningkatkan pengetahuan dan keterampilan khususnya ibu-ibu balita, dalam hal gizi dan kesehatan secara umum melalui poster, video edukasi yang dapat di akses oleh masyarakat yang saat ini sudah sebagian besar memiliki handphone android. Dengan harapan bisa membantu meningkatkan keadaan gizi balita di daerah tersebut.

\section{Metode Pelaksanaan}

Kegiatan pengabmas yang dilaksanakan ialah pemberian edukasi terkait gizi seimbang balita dalam meningkatkan imunitas balita masa pandemi Covid-19 kepada kelompok ibu-ibu balita di Kelurahan Anduring. 


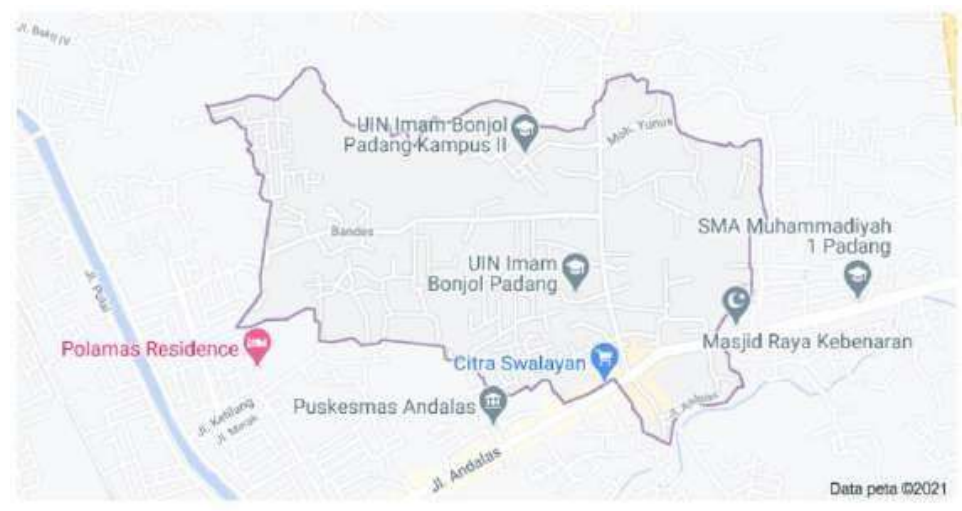

Anduring

Kec. Kuranji, Kota Padang, Sumatera Barat

Sumber: (Google-Maps, 2020)

\section{Gambar 1. Peta Kelurahan Anduring}

Pada tahap persiapan terlebih dahulu tim abdimas melakukan identifikasi permasalahan kelompok sasaran yaitu Ibu Balita yang ada di Kelurahan Anduring. Identifikasi permasalahan mitra dilakukan dengan berdiskusi daring dengan Ibu ketua PKK, kader kesehatan, pihak Puskesmas Ambacang dimana Kelurahan Anduring merupakan salah satu wilayah kerjanya dan ibu Balita di Kelurahan Anduring yang dilaksanakan pada tanggal 26 September 2020. Selain itu juga diidentifikasi dari informasi dan data-data sekunder yang didapatkan dari dinas terkait. Tahap selanjutnya dilakukan dengan rapat koordinasi dengan pihak Kelurahan Anduring dan kader-kader di Kelurahan Anduring pada tanggal 2 Oktober 2020. Hasil rapat koordinasi menjadi bahan dalam penyusunan rencana pelaksanaan kegiatan, dimana pelaksanaannya dilakukan dengan mematuhi protokol kesehatan sehubungan dengan adanya pandemi COVID-19.

Pelaksanaan kegiatan diawali dengan penandatanganan MoU dilanjutkan dengan MoA dengan Kelurahan Anduring yang dilaksanakan pada tanggal 8 Oktober 2020, dilanjutkan dengan pemberian edukasi dengan topik "Mendeteksi gangguan gizi pada anak dan Menu seimbang untuk kecukupan gizi balita" pada tanggal 15 Desember 2020. Pemberian edukasi dilanjutkan dengan mengirimkan informasi berupa poster/leaflet melalui grup WhatsApp. Tahap evaluasi dilakukan dengan pemberian kuisioner pre test pada saat sebelum pemberian materi dan kuisioner post test saat setelah selesai pemberian materi kepada sasaran untuk mengukur pengetahuan sasaran terkait materi yang diberikan. Data dianalisa secara univariat untuk melihat gambaran rata-rata hasil pre dan post test dari hasil pemberian materi kepada sasaran.

\section{Hasil}

\section{Pemberian Materi kepada Sarasan}

Pemberian edukasi tentang gizi seimbang balita dalam meningkatkan imuntas balita masa pandemi COVID-19 kepada kelompok ibu-ibu balita di Kelurahan Anduring dilaksanakan pada hari Selasa, tanggal 15 Desember 2020. Pelaksanaan kegiatan bertempat di ruang pertemuan Kelurahan Anduring dengan cara tatap muka di kelas 
secara terstruktur. Sebelumnya pada tanggal 8 Oktober telah dilaksanakan penandatanganan kerjasama dengan Kelurahan Anduring yang juga dihadiri langsung oleh Sekretaris Camat, Kecamatan Kuranji, dan Kepala Puskesmas Ambacang. Sehubungan penyelenggaraan kegiatan penyuluhan saat pandemi COVID-19 berlangsung maka kegiatan penyuluhan dilaksanakan dengan mematuhi protokol kesehatan COVID-19. Sebelum memasuki ruangan semua peserta penyuluhan diwajibkan mencuci tangan dengan sabun, memakai masker dan dilakukan pengukuran suhu tubuh untuk memastikan semua peserta dalam keadaan sehat.

Jumlah sasaran yang hadir pada kegiatan pemberian edukasi tentang gizi seimbang balita sebanyak 20 orang ibu-ibu balita. Rata-rata usia ibu yang menjadi sasaran ialah 30,89 \pm 5,507 tahun. Rata-rata ibu memiliki 2-3 orang anak dan paling banyak memiliki 4 orang anak. Seluruh ibu (100\%) merupakan Ibu Rumah Tangga. Adapun gambaran karakteristik sasaran dapat dilihat pada tabel 1 berikut:

Tabel 1. Gambaran Karaktersitk Sasaran

\begin{tabular}{ccccc}
\hline Karaktersitik & Min & Max & Mean & Std. Deviasi \\
\hline Usia responden & 19 & 41 & 30,89 & 5,507 \\
Jumlah anak & 1 & 4 & 2,5 & 0,99 \\
\hline
\end{tabular}

\begin{tabular}{ccc}
\hline Pekerjaan responden & f & \% \\
\hline Ibu Rumah tangga & 20 & 100 \\
\hline
\end{tabular}

Adapun materi yang disampaikan berupa: 1) Mendeteksi gangguan gizi pada anak oleh narasumber Sunesni, S.SiT, M.Biomed dan 2) Menu seimbang untuk kecukupan gizi balita dan contoh menu cemilan sehat Balita oleh narasumber Yani Maidelwita, SKM, M.Biomed.

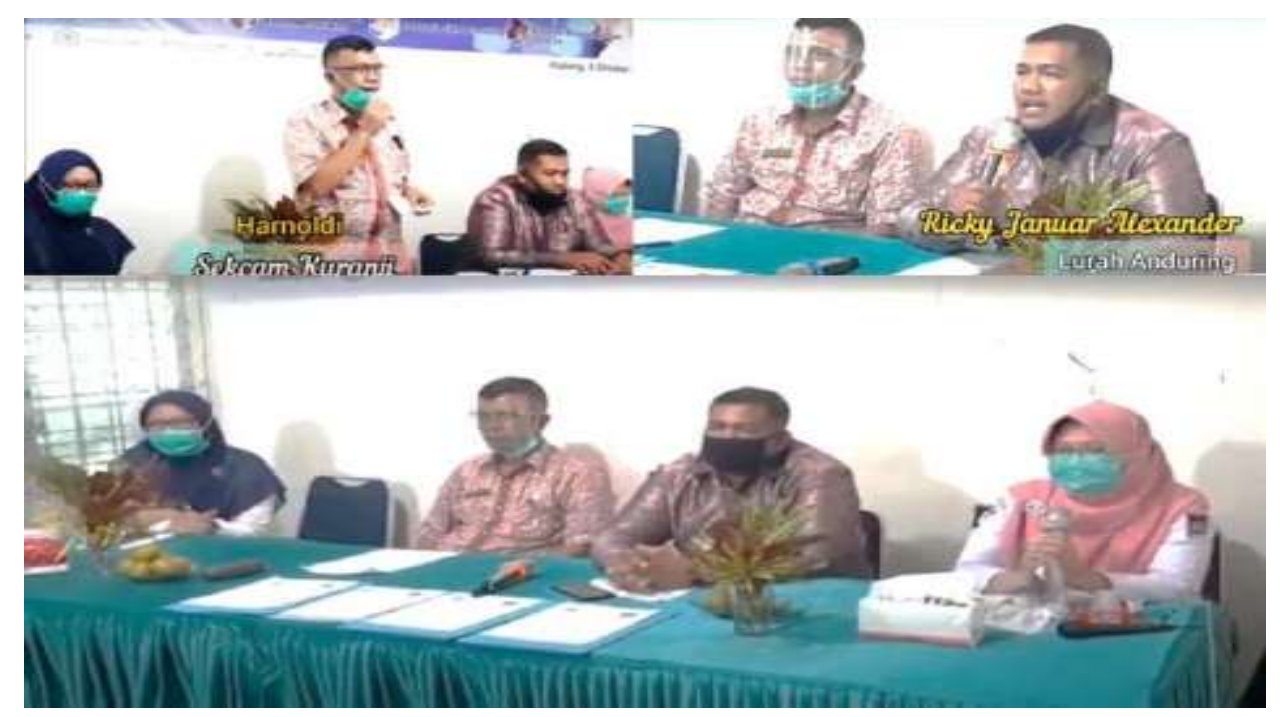

Gambar 2. Kegiatan Penandatanganan MoU dan MoA dengan Kelurahan Anduring 


\section{Jurnal ABDI MERCUSUAR}

Vol. 01, No. 02, Desember , 2021, pp. 029 - 037

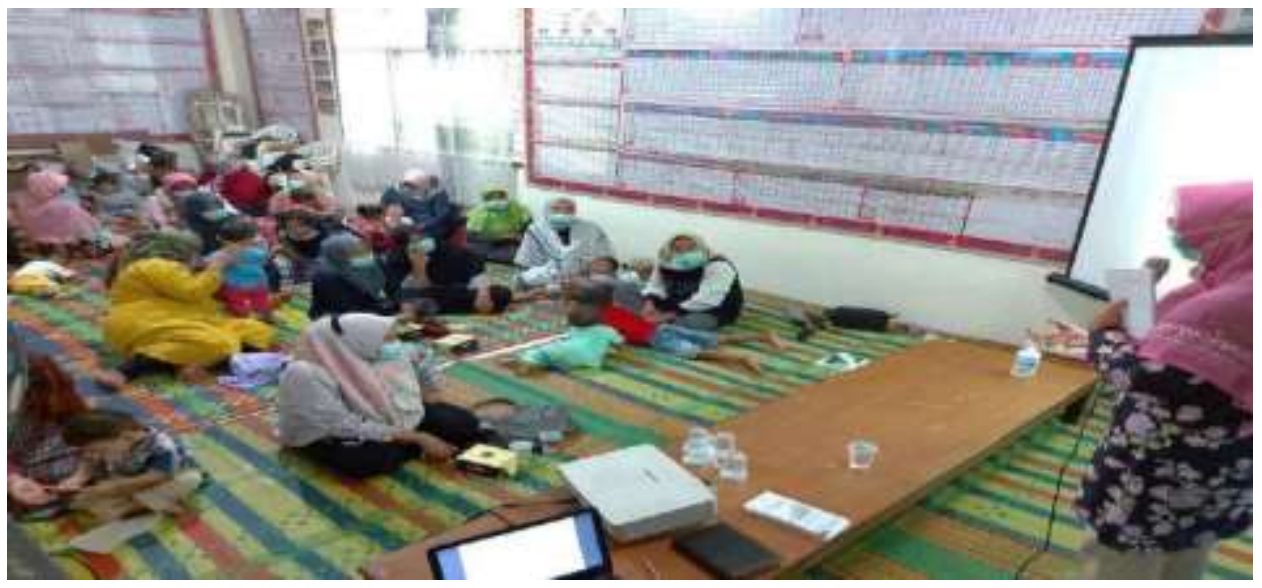

Gambar 3. Pemberian Materi tentang Mendeteksi Gangguan Gizi pada Anak oleh Sunesni, S.SiT

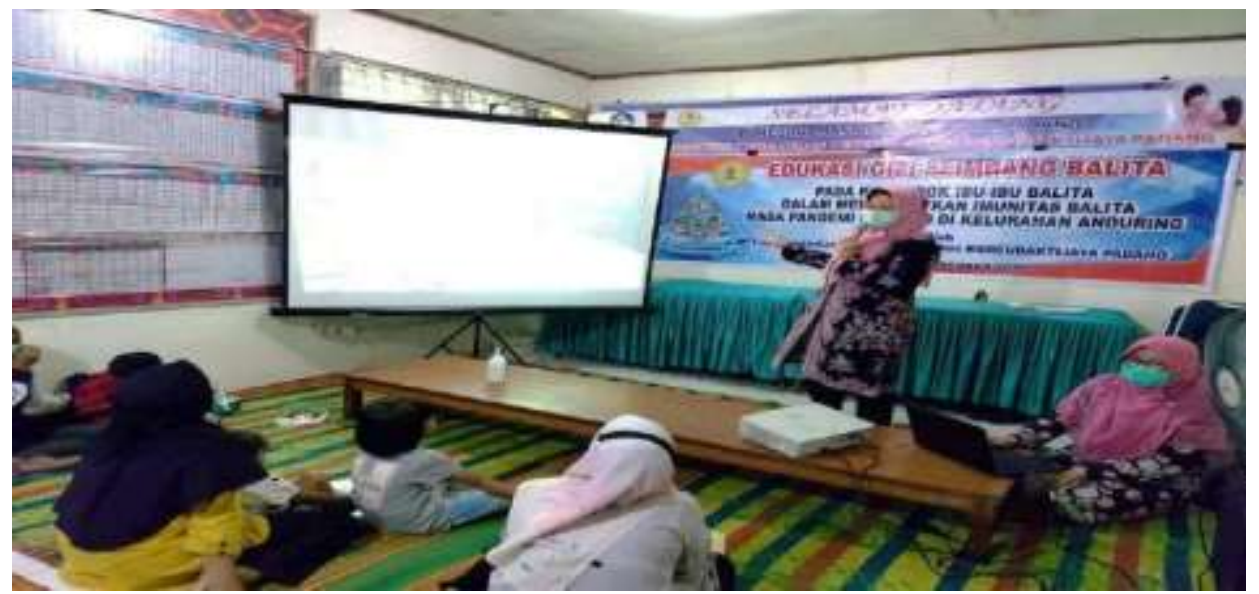

Gambar 4. Pemberian Materi Gizi Seimbang untuk Balita pada masa Pandemi Covid-19 oleh Yani Maidelwita, SKM, M.Biomed

\section{Monitoring dan Evaluasi}

Monitoring dan evaluasi (monev) dilakukan oleh tim pengabdi dengan memberikan kuisioner pre test dan post test kepada responden untuk melihat gambaran pengetahuan responden sebelum diberikan materi dan sesudah diberikan materi penyuluhan. Hasil pre test dan post test dapat dilihat pada tabel berikut:

Tabel 2. Gambaran Hasil Pre Test dan Post Test Pengetahuan terkait Materi Tanda-Tanda Anak Sehat dan Status Gizi pada Balita

\begin{tabular}{ccccc}
\hline Pengetahuan & Min & Max & Mean & Std. Deviasi \\
\hline Pre Test & 47 & 93 & 72,70 & 11,824 \\
Post Test & 60 & 93 & 77,55 & 9,495 \\
\hline
\end{tabular}

Nilai rata-rata pengetahuan responden mengalami peningkatan dari sebelum dan setelah dilakukan edukasi, dimana saat awal rata-rata pengetahuan ibu-ibu balita di Kelurahan Anduring adalah 72,70 $\pm 11,824$ dan saat akhir setelah edukasi menjadi $77,55 \pm 9,495$ (Tabel 2). 


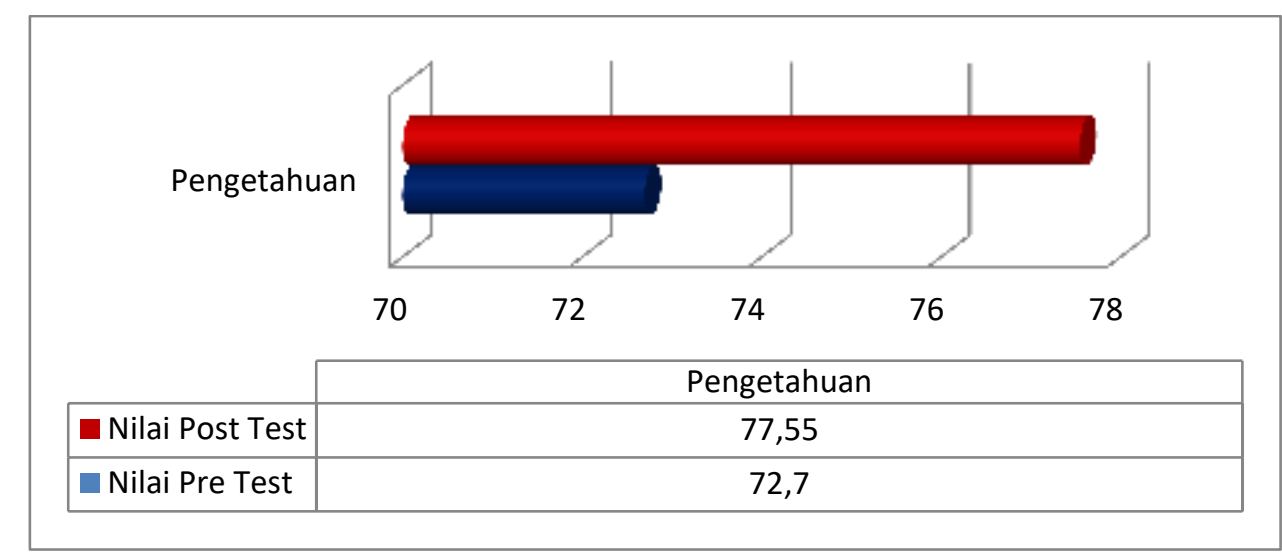

\section{Gambar 5. Grafik Peningkatan Skor Pengetahuan Hasil Pre Test dan Post Test}

\section{Diskusi}

Hal yang harus dilakukan untuk meningkatkan sistem kekebatan tubuh yang baik adalah menjaga pola makan gizi seimbang yang sehat. Meningkatkan imunitas/daya tahan tubuh merupakan kunci perlindungan agar tidak tertular virus Covid-19 terutama pada kelompok rentan, satunya yaitu balita. Banyak perubahan yang terjadi dalam kehidupan sehari-hari selama masa pandemi Covid-19 berlangsung dan masyarakat pada umumnya harus bisa beradaptasi untuk menghadapi situasi ini (Kemenkes RI, 2020).

Walaupun tidak ada jenis makanan spesifik atupun suplemen khusus yang dapat mencegah terjadinya Covid-19, namun mengkomsumsi gizi yang baik dan seimbang sangat diperlukan baik sebelum, selama dan setelah infeksi. Sebelum terjadi infeksi tubuh kita memerlukan gizi sebagai bahan baku sistem imunitas tubuh. Saat terjadi Infeksi tubuh akan menunjukkan rekasi demam, sehingga membutuhkan tambahan energi dan zat gizi. Begitu juga saat setelah infeksi tubuh kita membutuhkan energi dan zat gizi untuk proses pemulihan (Kemenkes RI, 2020). Untuk itu diperlukan pemberian edukasi kepada masyarakat terkait gizi seimbang pada masa pandemi Covid-19 ini.

Metode pemberian edukasi dapat dilakukan dengan berbagai cara, baik dengan pertemuan secara langsung maupun tidak langsung. Seiring dengan perkembangan teknologi dan informasi dan tuntutan kondisi di masa pandemi Covid-19 metode edukasi ke masyarakat harus dikembangkan dengan memanfaatkan berbagai macam aplikasi digital yang memudahkan penyampaian pesan kepada sasaran (Permatasari, et al., 2020). Dari hasil evaluasi kegiatan pemberian edukasi gizi seimbang balita pada kelompok Ibu-Ibu Balita dalam Meningkatkan Imuntas Balita Masa Pandemi Covid-19 di Kelurahan Anduring Kota Padang didapatkan adanya peningkatan pengetahuan dari sebelum dan setelah dilakukan edukasi, dimana saat awal rata-rata pengetahuan ibuibu balita di Kelurahan Anduring adalah 72,70 \pm 11,824 dan saat akhir setelah edukasi menjadi 77,55 $\pm 9,495$. 
Hal tersebut sebanding dengan hasil kegiatan pengabdian kepada masyarakat oleh Pertamasari, dkk tahun 2020 tentang Edukasi Gizi Seimbang bagi Kader Posyandu pada Masa Pandemi Covid-19 sebagai Pencegahan Balita Stunting di Kabupaten Bogor, dimana terjadi peningkatan rata-rata skor pengetahuan mengenai gizi seimbang terkait pencegahan terjadinya stunting pada balita dari $77,52 \pm 10,82$ SD saat pre-test menjadi 82,19 $\pm 9,93$ SD saat post test (Permatasari, et al., 2020).

Gizi merupakan fondasi mencitakan generasi yang tangguh dan sehat. Kebutuhan gizi seimbang sangat penting dipenuhi untuk meningkatkan daya tahan tubuh, terlebih pada masa pandemic Covid-19. Pandemi Covid-19 menuntut setiap individu untuk berusaha ekstra dalam menjaga dan meningkatkan sistem kekebalan tubuh dengan. Hal ini dikarenakan, sistem imun yang baik merupakan benteng pertahanan tubuh yang ampuh dalam menghadapi virus (Yuniarto, 2021).

\section{Kesimpulan dan Saran}

Pemenuhan kebutuhan gizi seimbang pada Balita, sangat diperlukan dalam meningkatkan sistem imunitas guna memperkuat pertahanan tubuh dalam menghadapi virus Covid-19. Kegiatan edukasi yang dilakukan memberikan wawasan tambahan terkait materi deteksi gangguan gizi pada anak dan gizi seimbang untuk balita pada masa pandemi Covid-19 bagi kelompok ibu-ibu di kelurahan Anduring. Adanya pandemi Covid-19 yang membatasi kegiatan berkelompok harusnya tidak menghentikan kegiatan dengan tujuan memberikan edukasi kesehatan ke masyarakat, bisa dengan pertemuan langsung dengan menerapkan protokol kesehatan ataupun dengan memanfaatkan media daring/online.

\section{Ucapan Terimakasih}

Kami ucapkan terima kasih kepada Yayasan MERCUBAKTIJAYA, STIKes MERCUBAKTIJAYA Padang, LP2M STIKes MERCUBAKTIJAYA Padang, Kelurahan Anduring Kota Padang serta Ibu-ibu Kader di Kelurahan Anduring telah yang telah memberikan dukungan dalam pelaksanaan pengabdian masyarakat ini sehingga bisa terlaksana dengan baik.

\section{Daftar Referensi}

Arisman. (2011). Perbaikan Gizi Anak. Jakarta: EGC.

BPS, B. (2020). Kecamatan Kuranji Dalam Angka 2020. Padang: BPS, Badan Pusat Statistik.

Dinkes Surakarta. (2020). Stunting di Era Pandemi Covid-19. Retrieved November 2021, 2021, from Dinas Kesehatan Kota Surakarta: https://dinkes.surakarta.go.id/stunting-di-era-pandemi-covid-19/

Google-Maps. (2020). Google Maps. Retrieved from Google Maps: https://www.google.com/maps/dir/STIKes+MERCUBAKTIJAYA,+Surau+Gadang ,+Padang+City,+West+Sumatra/Kantor+LURAH+ANDURING,+Anduring,+Kota+P adang,+Sumatera+Barat/@0.9157043,100.3631911,14z/data=!3m1!4b1!4m13! 4m12!1m5!1m1!1s0x2fd4b8983aa72b57:0xe6aa012fd0e8fc2b 
Google-Maps. (2020). Google Maps. Retrieved from Google Maps: https://www.google.com/maps/place/Anduring,+Kec.+Kuranji,+Kota+Padang,+ Sumatera+Barat/@0.9335604,100.3756727,15z/data=!3m1!4b1!4m5!3m4!1s0x 2fd4b904a4f214c1:0xcca0bfb58df8a8ac!8m2!3d-0.9342602!4d100.384883

Kemenkes RI. (2020). Panduan Gizi Seimbang Pada Masa PAndemi COVID-19. Jakarta: Kementerian Kesehatan Republik Indonesia.

Permatasari, T. A., Turrahmi, H., \& Illavina. (2020). Edukasi Gizi Seimbang bagi Kader Posyandu pada Masa PAndemi Covid-19 sebagai Pencegahan Baita Stunting di Kabupaten Bogor. AS-SYIFA: Jurnal Pengabdian dan Pemberdayaan Kesehatan MAsyarakat, Volume. 1 No. 2 (67-77).

UNICEF. (2017). Anak-Anak di Indonesia: Analisis Kemiskinan, Mobilitas dan Kekurangan Multidimensi. Jakarta: UNICEF.

UNICEF. (2018). Kajian Kapasitas Negara Memenuhi Kebituhan Gizi. Jakarta: UNICEF Indonesia.

Yuniarto, T. (2021, Februari 19). Komsumsi Gizi Seimbang pada Masa Pandemi. Retrieved from kompaspedia.kompas.id: https://kompaspedia.kompas.id/baca/paparan-topik/konsumsi-gizi-seimbang pada-masa-pandemi 